\title{
Wetlands in Your County:
}

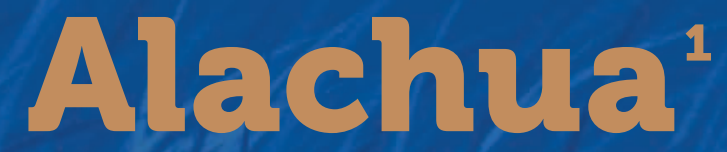

Mark W. Clark, Stacie Greco and Susan Curry²

\section{Introduction}

Wetlands, a unique type of environment in the Florida landscape, consist of a mix of both terrestrial and aquatic ecosystems. These areas provide valuable environmental services in the form of wildlife habitat, plant biodiversity, flood control, groundwater recharge, carbon storage and improved water quality. Over the past 200 years, Florida has lost roughly half of its original estimated 20.3 million acres of wetlands. The remaining wetlands now cover approximately $30 \%$ of the state. Some of these remaining wetlands are well known, such as the Florida Everglades, while others may be small and unassuming. Wetlands can be found in every county in Florida and are diverse in both their location in the landscape as well as the type of soils and vegetation that develop. This factsheet is one in a series that provides specific information about wetlands in Alachua County.

\section{Wetlands in Alachua County}

There are an estimated 94,386 acres of wetlands that cover $18 \%$ of Alachua County (Figure 1). Most of the wetlands found in the county are mixed hardwood and coniferous swamps (52\%) and freshwater marshes (25\%) with numerous mixed scrub-shrub (9.0\%), wet prairie (6.8\%) and cypress swamps (6.2\%) present (Table 1). The largest contiguous wetland in the county is Payne's Prairie, an herbaceous scrub-shrub complex just south of Gainesville. There are also extensive freshwater marshes south and southwest of Payne's Prairie associated with Levy Lake, Ledwith Lake, Orange Lake and Lake Lochloosa. Along the county's northern border, extensive floodplains occur along the Santa Fe River. There are also smaller

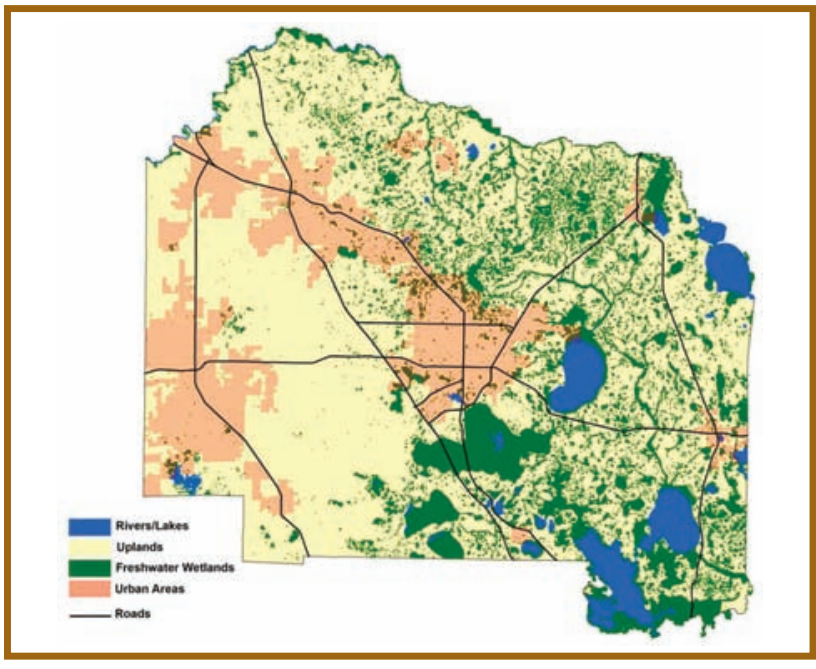

Figure 1. Distribution of lakes, uplands and wetlands in Alachua County.

but numerous cypress ponds or domes that dot the pine flatwoods to the north and east of Gainesville. Wetlands primarily occur in the eastern two thirds of the county due to differences in the underlying geology. In the eastern and northern part of the county, a thick clay layer called the Hawthorne Formation reduces infiltration rates and keeps water near the surface. In the western third of the county the Hawthorne Formation has eroded and water infiltrates quickly down below the surface and into the surficial aquifer.

Although there are strong regulations to protect wetlands from direct impacts such as drainage and filling, indirect impacts, such as changes in hydrology and water pollution, can still result in significant loss of function. Knowing the type of land use adjacent to a wetland

${ }^{1}$ This document is SL 307, one of a series of the Soil and Water Science Department, Florida Cooperative Extension Service, Institute of Food and Agricultural Sciences, University of Florida. Original publication date December 2009. Visit the EDIS Web Site at http://edis.ifas.ufl.edu.

${ }^{2}$ Mark W. Clark, assistant professor, Wetlands and Water Quality, Department of Soil and Water Science; Stacie Greco, senior environmental specialist, Alachua County Environmental Protection Department, Gainesville FL; Susan Curry, educational coordinator, Department of Soil and Water Science; Florida Cooperative Extension Service, Institute of Food and Agricultural Sciences, University of Florida, Gainesville, FL 32611. 
Table 1. This table shows the acreage, percent distribution and predominant adjacent land uses among dominant wetland types occurring in Alachua County

\begin{tabular}{|c|c|c|c|c|c|c|}
\hline \multirow[b]{2}{*}{ Wetland Type } & \multirow[b]{2}{*}{$\begin{array}{l}\text { Wetland } \\
\text { Acreage }\end{array}$} & \multirow[b]{2}{*}{$\begin{array}{c}\% \\
\text { Wetland } \\
\text { Type }\end{array}$} & \multicolumn{4}{|c|}{ Wetlands Edge Adjacent to Land Use Type } \\
\hline & & & Agriculture & Silviculture & Urban & Other* \\
\hline mixed swamp & 39,710 & $42.1 \%$ & $9.4 \%$ & $43.1 \%$ & $6.0 \%$ & $41.5 \%$ \\
\hline freshwater marsh & 23,619 & $25.0 \%$ & $9.0 \%$ & $10.9 \%$ & $2.7 \%$ & $77.5 \%$ \\
\hline scrub-shrub wetland & 8,478 & $9.0 \%$ & $6.5 \%$ & $19.6 \%$ & $4.2 \%$ & $69.6 \%$ \\
\hline wet prairie & 6,447 & $6.8 \%$ & $16.6 \%$ & $12.5 \%$ & $1.6 \%$ & $69.3 \%$ \\
\hline cypress swamp & 5,838 & $6.2 \%$ & $5.6 \%$ & $21.4 \%$ & $4.1 \%$ & $68.9 \%$ \\
\hline hardwood swamp & 3,414 & $3.6 \%$ & $1.6 \%$ & $11.0 \%$ & $4.0 \%$ & $83.5 \%$ \\
\hline $\begin{array}{l}\text { mixed hardwood } \\
\text { swamp }\end{array}$ & 3,282 & $3.5 \%$ & $9.3 \%$ & $18.6 \%$ & $3.0 \%$ & $69.1 \%$ \\
\hline $\begin{array}{l}\text { mixed coniferous } \\
\text { swamp }\end{array}$ & 3,054 & $3.2 \%$ & $2.8 \%$ & $43.9 \%$ & $1.8 \%$ & $51.6 \%$ \\
\hline other wetlands & 544 & $0.6 \%$ & $17.0 \%$ & $27.6 \%$ & $0.1 \%$ & $55.3 \%$ \\
\hline All Wetlands & 94,386 & $100.0 \%$ & $8.6 \%$ & $29.9 \%$ & $4.5 \%$ & $57.0 \%$ \\
\hline
\end{tabular}

*This adjacent land use category can include natural areas, open water and other wetland types.

provides some indication of how disturbed the wetland may be. Wetlands adjacent to urban and agricultural areas often show signs of hydrologic impacts, reductions in wildlife and wildlife habitat, altered plant community succession due to lower fire frequency, increases in exotic plant and animal species, as well as changes in water quality. The degree of indirect impact is often related to the intensity of the adjacent land use and the extent to which alterations in water quantity and quality are mitigated before they reach the wetland. In Alachua County, 57\% of wetland community edges are adjacent to minimally disturbed land, which may include other wetlands, while $8.6 \%$ are adjacent to agriculture land, $4.5 \%$ are adjacent to urban land uses and $29.9 \%$ are adjacent to silviculture activities (Table 1).

Although wetlands are often combined as one type of ecosystem, from an ecological perspective wetlands are very diverse in both structure and function. The plants that occur in a wetland are mostly determined by their ability to survive under the flooding conditions that occur and their tolerance to fire. Wetlands that have short periods of flooding with infrequent fire often develop into hardwood swamps. Wetlands with long periods of flooding and/or frequent fires typically develop into herbaceous marshes or prairies. Wetlands where hydrology, fire, or some other environmental condition like nutrient availability may be changing will result in a mix of these wetlands types until the environmental conditions stabilize and enough time has passed to establish a new type of wetland community. The following section provides more detail about wetland types often found in Alachua County. 


\section{Description of Wetland Types Occurring in Alachua County}

Mixed Swamp

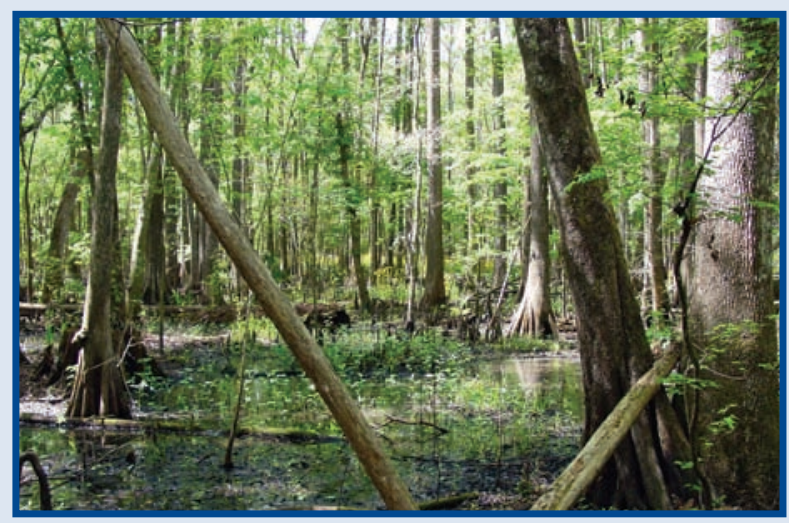

Forested wetlands where neither hardwood nor conifer species account for more than $66 \%$ of the crown canopy composition. Species consist of a mix of trees listed under Hardwood Swamp and Mixed Coniferous swamp.

Freshwater Marshes

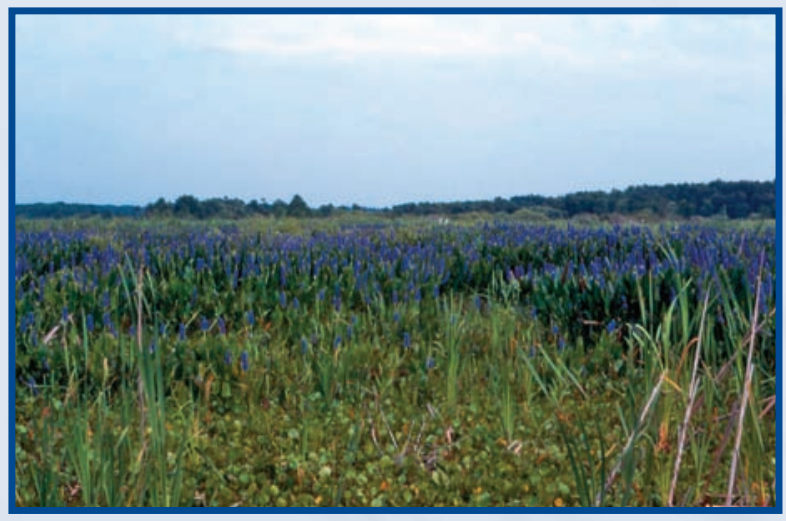

These wetlands are dominated by herbaceous vegetation and have a wide range of hydrologic conditions. Typical species found in this system are Sawgrass (Cladium jamaicense), Cattail (Typha spp.), Arrowhead (Sagittaria spp.), Maidencane (Panicum hemitomon), Buttonbush - (Cephalanthus occidentalis), Giant Cutgrass (Zizaniopsis miliacea), Bulrush (Scirpus spp.), Needlerush (Juncus spp.), and Pickerelweed (Pontederia cordata).
Scrub Shrub Swamp

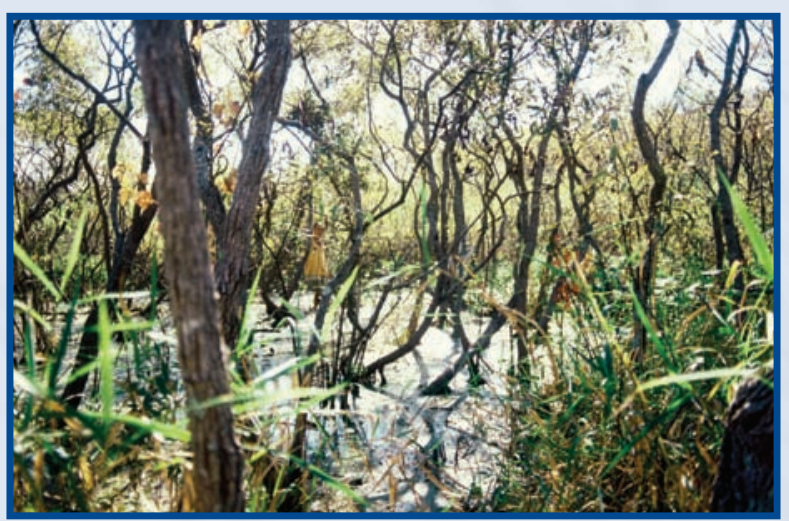

These wetlands are dominated by shrubs but may contain a mix of immature trees and an herbaceous understory. These systems are usually transitional between marshes and forested swamps, or the result of suppressed fire. Dominant species in the northern part of the state are willows (Salix spp.), Black Titi (Cliftonia monophylla) and Titi (Cyrilla racemiflora). Dominant species in the southern part of the state include Willow (Salix spp.) and Pond Apple (Annona glabra).

\section{Wet Prairies}

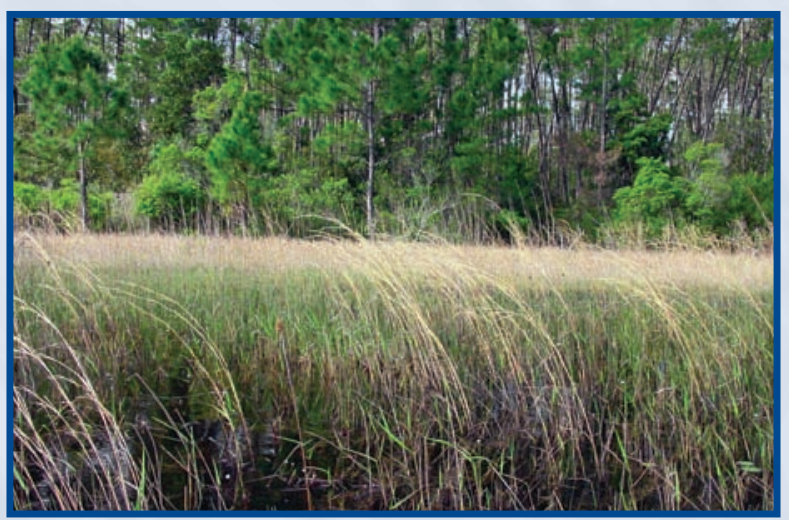

Wetlands predominantly dominated by grasses or sedges and distinguishable from marshes by having less water and shorter vegetation. Common species include Maidencane (Pamicum hemitomon), Cordgrasses (Spartina bakeri), Spike Rushes (Eleocharis spp.), Beak Rushes (Rhynchospora spp.), Yellow-eyed Grass (Xyris ambigua), and St. Johns-wort (Hypericum spp.). 


\section{Cypress Swamp}

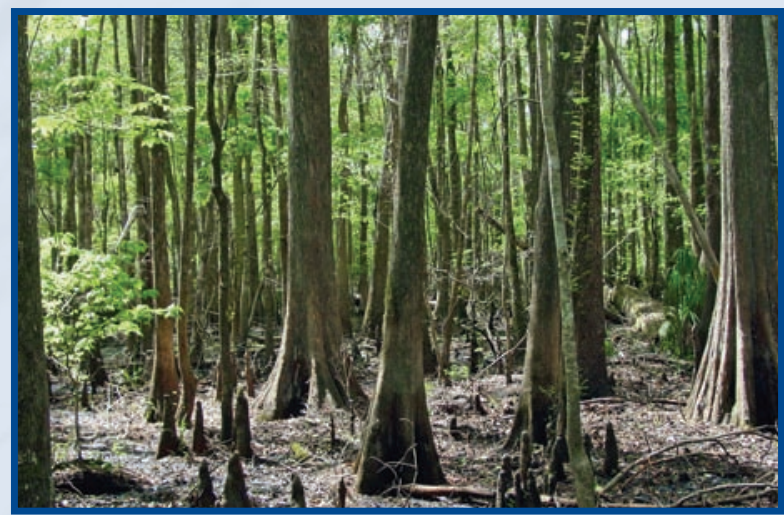

This community is predominately composed of either pond cypress (Taxodium ascendens) or bald cypress (Taxodium distichum). Pond cypress is typically found in more isolated depressions and sloughs associated with pine flatwoods. Bald cypress is more typically found in fringing wetlands around lakes or in riparian wetlands along rivers and streams.

\section{Hardwood Swamp}

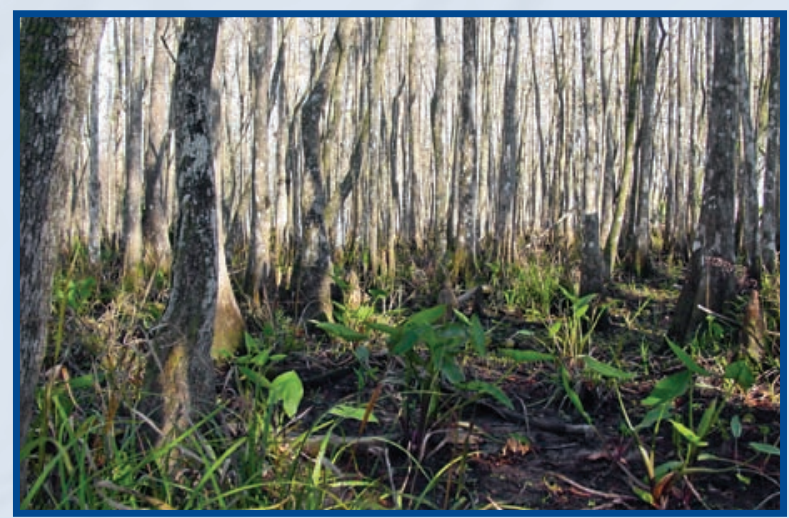

Forested wetlands are composed of a variety of hardwood species that are tolerant of a range of flooded conditions. Communities, such as Bay Swamps, can consist of a few dominant species like Loblolly Bay (Gordonia lasianthus), Sweetbay Magnolia (Magnolia virginiana), and Swamp Bay (Persea palustris), while Gum swamps are generally dominated by Swamp Tupelo (Nyssa sylvatica var. biflora), Water Tupelo (Nyssa aquatica) and Ogeechee Tupelo (Nyssa ogeche). Hardwood Swamps can also be mix of hardwood species including Red Maple (Acer rubrum), River Birch (Betula nigra), Water oak (Quercus nigra), Sweetgum (Liquidambar styraciflua), Ash (Fraxinus spp.) and Hickory (Carya spp.). They often occur along riparian floodplains or landward of fringing cypress wetlands.

\section{Mixed Coniferous Swamp}

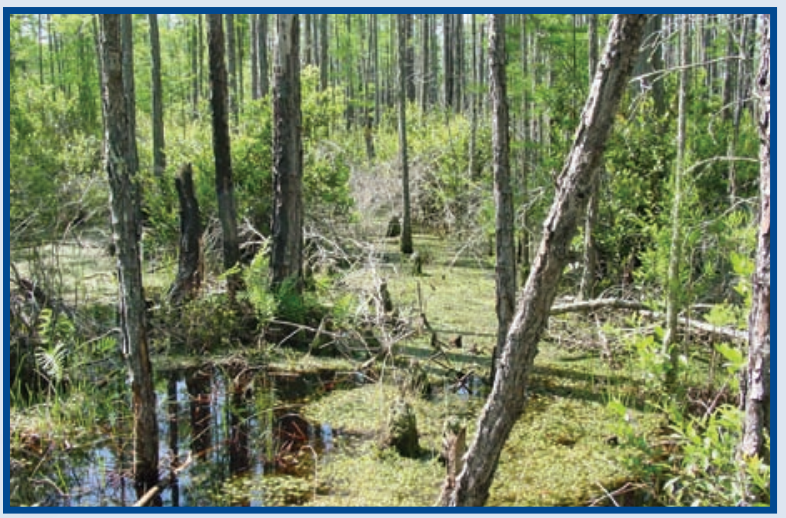

These wetland forests are made up of a mix of cone bearing trees which may include cypress, but at less than $66 \%$ of the canopy. Species common to this community other than cypress include Slash Pine (Pinus elliotii), Loblolly Pine (Pinus taeda), Spruce Pine (Pinus galabra), Pond Pine (Pinus serotina) and Atlantic White Cedar (Chamaecyparis thyoides). These communities are commonly found in interior wetlands, which occur in river flood plains, bogs, bayheads and sloughs. 


\section{Additional Resources}

Interactive Wetlands Website

The United States Fish and Wildlife Service provides an interactive website called Wetlands Mapper. This web based tool allows you to zoom in to a high level of resolution and determine what type of wetlands may be present at a location of interest. http://www.fws.gov/wetlands/ Data/mapper.html.

\section{Public Access Wetlands}

There are multiple wetlands within Alachua County that provide public access so that you can see these systems first hand. A few of these public access locations can be found at: http://wetlandextension.ifas.ufl.edu/ counties/alachua.htm.

\section{Land Use Data and Calculations}

Information Sources and Land Use Classification Land use data was obtained from one or more of Florida's Water Management Districts that based their interpretation on 1995 aerial imagery. Land uses were determined by photo interpretation of 1:40,000 USGS NAPP color infrared photographs. Land use classifications were based on a modified version of the statewide Florida Land Use and Cover Classification System (FLUCCS) maintained by FDOT. Modifications were mainly the result of aggregating level III classifications in the following manner.

i) Urban Lands: all FLUCCS codes between 1000 and 1999 (urban), and between 8000 and 8999 (transportation)

ii) Agricultural Lands: all FLUCCS codes between 2000-2999

iii) Silviculture Lands: all FLUCCS codes between 4400-4499

iv) Open Water: all FLUCCS codes between 5000-5999

v) Other/Minimally Disturbed: all other land use FLUCCS codes not otherwise classified were considered minimally disturbed. 3000-3999 (rangeland), 4000-4399 (native upland forest), 6000-6999 (wetland)
Wetland Community types

Wetland community classifications were based on aggregating within level III FLUCCS classifications 6000-6999. Full FLUCCS classification definitions can be found at http://www.dot.state.fl.us/surveyingandmapping/ Manuals/fluccmanual.pdf with the modified definitions outlined in text above.

Adjacent Land Use Interpretation

To determine the percent of land use adjacent to each wetland type, a one meter digital buffer was placed around wetland polygons using ArcGIS. The distance of one meter corresponds to the pixel resolution of the land use coverage data. Using the clip tool in ArcGIS the land use underlying the one meter buffer was determined and summed for all wetlands adjacent to that land use type in the county. By dividing the buffer area of a particular land use type by the total buffer area around wetlands in the county, the percentage of wetland perimeter adjacent to a particular land use type was estimated. Although calculations were based on the area under the one meter buffer, it is probably more accurate to interpret this value as the percentage of wetland edge or perimeter adjacent to a particular land use type and not an area of overlap.

\section{For more information contact}

Mark W. Clark

Soil and Water Science Department clarkmw@ufl.edu

\section{UF | FLORIDA \\ IFAS Extension}

The Institute of Food and Agricultural Sciences (IFAS) is an Equal Opportunity Institution authorized to provide research, educational information and other services only to individuals and institutions that function with non-discrimination with respect to race, creed, color, religion, age, disability, sex, sexual orientation, marital status, national origin, political opinions or affiliations. For more information on obtaining other extension publications, contact your county Cooperative Extension service.

U.S. Department of Agriculture, Cooperative Extension Service, University of Florida, IFAS, Florida A. \& M. University Cooperative Extension Program, and Boards of County Commissioners Cooperating. Millie Ferrer-Chancy, Interim Dean 